\title{
Research on Patriotic Education of College Students in the New Era
}

\author{
Ying Ji \\ Oxbridge College, Kunming University of Science and Technology, Kunming, 650000, China
}

\author{
Keywords: New era, College students, Patriotic education, Research
}

\begin{abstract}
Patriotism education occupies an important position in the college education, university leaders and teachers must pay more attention to patriotism education, take effective measures to carry out patriotic education, cultivate students' patriotic consciousness, only in this way can provide a large number of talents for the development of the country. This paper further studies the college patriotic education, illustrates my own suggestions in the hope of helping patriotic education in a better way.
\end{abstract}

\section{Introduction}

In college education, patriotic education has a pivotal position, patriotic education is not only to cultivate students' patriotic consciousness, but also the forces to promote the development of our country. In view of the importance of patriotic education, teachers should pay more attention to patriotic education, take effective measures to tackle the problems we had in patriotic education to improve the teaching quality and realize the objectives of patriotic education.

\section{Problems in the current patriotic education of college students}

\section{Vague understanding and confusion in college students.}

College Students' cultural quality is relatively high, and most of them have a sense of patriotism. They love their own country, know their own responsibility, and work hard to develop China, but the influence of the market impact leads to ideological confusion for many students, which are manifested by the following aspects: first, confusion on patriotic awareness, students do have a sense of patriotism, but it's not solid or stable; second, with the development of social economy, students' value are changing and diversified; third, some students do not have confidence in the national development, incorrect understanding of the characteristics of the global economic integration.

\section{Problems in patriotic education in Colleges}

The patriotism education in Colleges has some problems as follows: first, teachers are not paying enough attention to the education of patriotism or not have adequate awareness to it. Many university teachers think that the patriotic consciousness is natural, education is not necessary. Some teachers do not realize the importance of patriotic education. If teachers do not have proper understanding of patriotic education, they won't pay high attention to it naturally, which will lead to low teaching efficiency[1]. Second, patriotic education system is not complete.because the patriotic education awareness is lacking, the system is not through, patriotic education in such system won't have high efficiency; Third, patriotic education in many colleges and universities do not meet the needs of social development. Society is changing, patriotic education should change accordingly, but in reality, teachers are not changing the education model, they still use traditional model, which result in low efficiency of patriotic education and failure of teaching goals.

\section{The principle of carrying out patriotic education in Colleges}

In the process of carrying out patriotic education in Colleges and universities, we should follow the basic principle, the current development of patriotic education should follow the following 
principles: the principle of standardization, the principle of pertinence, the construction principle, the practice principle and the principle of hierarchy. This paper analysis the five principle as follows:

\section{Principle of pertinence}

Principle of pertinence require teachers to combine and integrate patriotic education with current situation of college students such as thinking, psychological needs,and the current hot spots and the characteristics of the times, and conduct patriotic education, on the above basis, improve teaching quality and achieve the teaching objectives [2].

\section{Hierarchy principle}

In the process of teaching, teachers should divide the current mindset of students into levels, and conduct patriotic education accordingly, and classify them into 3 levels, namely sentiment, ideas and behavior pattern. Classification is necessary to improve teaching efficiency and cultivate students' patriotic consciousness.

\section{Standardization principle}

Teachers should develop a scientific and reasonable education program according to the actual situation and the characteristics of the students, and at the same time, we should develop teaching system which is related to the patriotic education system. Conduct patriotic education as per system to standardize it.

\section{Practice principle}

Practice principle, as the name suggests, is to ask the university to create practical conditions for teachers to carry out patriotic education, to help students step out of school, to carry out a variety of social practice,and help teachers to better cultivate the patriotic consciousness of college students.

\section{Construction principle}

In the teaching process, teachers should follow the construction principle,under the guidance of this principle, teachers should make good teaching material, system, theory and foundation construction. Teaching material construction means that colleges, with references to a variety of materials, should prepare purposeful, rich and profound teaching materials so that efficiency can be achieved when teachers teach according to these materials. System construction means that the university should develop a sound teaching system, systems such as raising the national flag, patriotic knowledge contest and knowledge lectures. Teaching will be more standardized;theoretical construction, colleges and universities should conduct further study on patriotic education theory, and establish a patriotic education theory system, teachers carry out teaching in accordance with the theoretical system so as to improve teaching quality;foundation construction, namely,colleges and universities regard relevant memorial buildings, as well as historical monuments as patriotic education bases, colleges and universities can organize students to visit, carry out social practice[3].

\section{Main contents of patriotic education in Colleges and Universities}

\section{Socialism education}

In contemporary China, there is an inseparable connection between patriotism and socialism. Socialism can point out the right direction of development for patriotism, patriotism can be a good foundation for the development of socialism,one can promote the other. Affection of China in socialism is the common nature of socialism and patriotism. Therefore, the teachers should integrate socialism with the patriotism. Find the pattern in studying of history and current situations, to help students understand that if China wants to develop better, it should apply the socialism model, and only when China is in socialism can China be developed better. In view of the importance of socialism education, it's very important for teachers to improve their awareness of socialism 
education. Patriotic education can be promoted when the ability of socialism education is improved to set up right socialism development concept for the students.

\section{National traditional culture and national spirit education}

National traditional culture is the bridge to connect the country and the nation. The students have a deep understanding of Chinese traditional culture, have excellent national spirit,then, they can have self-confidence so they can draw essence from western culture and resist spread of negative culture in the process of global economic integration.

\section{National sovereignty and national security education}

National sovereignty is essential to a country, so protection of national sovereignty is the main embodiment of patriotism. With the gradual development of global economic integration, the patriotic education should not only be about protecting national sovereignty, but also protecting the economy, politics and science and technology. Therefore, teachers should raise risk awareness in patriotism education to help the students to set up a protective barrier in their mindset.

\section{People's education}

People are the main body of the country, if there is no people, there is no country. Therefore, teachers in Colleges and universities should pay more attention to education on caring for people, only when the students are able to think from the perspective of the public, and aware the mutual dependence nature, patriotism can get fully reflected[4]. Therefore,when teachers raises students' patriotic consciousness, they need to educate the students to love the people.

\section{Education of hard working}

Our present days are won in a hard way, it was build with blood from countless revolutionary martyrs. Therefore,teachers in Colleges and universities should pay attention to the education of hard work while carrying out patriotic education, Only when Students have a spirit of hard working, can they be fearless in the face of difficulties, bravely move forward.

\section{The main way to carry out patriotic education in Colleges and Universities}

\section{To strengthen the main role of class lesson, strengthen the effect of "Two Courses"}

For teachers to carry out patriotic education, the main position is the classroom, teachers use classroom as media to transfer knowledge to students, students use classroom as the carrier, to learn knowledge from teachers. Thus, classroom is the main position for teachers in Colleges and universities to carry out patriotic education, teachers must strengthen the role of the classroom to achieve teaching objectives. Patriotism occupies an important position in the "Two Courses" education, the "Two Courses" has a positive effect patriotic education. Patriotic education and "Two Courses" education share the same goal, they are to cultivate students' sense of patriotism, so that students can take Chinese national Development as their own responsibility, and to make efforts to promote national development. Therefore, teachers can appropriately strengthen their efforts and highlight patriotic education while carrying out the education of "Two Courses". Expand patriotic education involved in the teaching of "Two Courses" to innovate teaching mode, to improve the quality of classroom teaching and achieve the goal of teaching by effective teaching methods.

\section{Hold on-campus colorful cultural activities to create a good atmosphere for the patriotic education.}

College teachers can improve the level of patriotic education with rich and colorful cultural activities. Teachers can create a good environment for patriotic education by organizing cultural activities, students can achieve more in a specific environment. Teachers can create better study environment with following methods: 
First, use media to create a good teaching atmosphere, patriotic awareness education needs not only the classroom lessons, but also needs a good study environment with media. Such as: establish special column for patriotic education in newspapers, billboards etc. to introduce the struggle history of Chinese people to create intense patriotic atmosphere and influence students gradually.

Second, to carry out patriotic education and cultural activities, to cultivate students' sense of patriotism. Teachers can cultivate students' sense of patriotism classroom teaching, they can also achieve through holding cultural activities. For example, teachers can hold lectures,debate and essay activities to help students better understand the long history of our country, and to cultivate their sense of patriotism.

Third, the establishment of a sound etiquette system. China is a big country that values etiquette, teachers can make students understand the profoundness of Chinese culture to induce a strong patriotic feelings. Colleges and universities can help teachers cultivate students' patriotic consciousness by raising the national flag and singing the national anthem.

C.Strengthen social practice

Patriotic education is not abstract or empty preaching, it is specific knowledge, significance and conducts. If teachers want to stimulate students' patriotism, they must integrate patriotic education into specific practice. Only when the students step out of school to have specific understanding of the national situation, custom, to experience the contributions made by people to the development of our country, they can actually getting the sense of patriotism. In view of the significance of practice to the patriotic education, colleges and universities should emphasis on practice,include practice in the patriotic education programme, help students to understand patriotism through social investigation, volunteer activities to deepen their patriotic consciousness.

\section{Conclusion}

In summary, carry out patriotic education in colleges and universities is of great significance. there are still some problems, these problems seriously affected the patriotic education effectiveness. In view of this situation, teachers in Colleges and universities should take effective measures to solve the problems existing in the patriotic education, and apply innovate teaching methods to carry out patriotic education, so as to promote the development of patriotic education. In addition, teachers should also combine patriotic education with the characteristics and development of the times, the current situation of our country and economic development and other factors,implement patriotism education, achieve the goal of patriotic education to cultivate students' Patriotism Consciousness.

\section{References}

[1] Wang Jun, Tian Xiaofang. The Approach and Method to Guide College Students' Rational Patriotism in the New Period. Journal of Chengdu Normal College, 2013,29 (10): 25-28.

[2] Paul Liu, Xu Chuanzhou, Xu Yan etc. The Challenges and Countermeasures of College Students' Patriotism Education in the New Period. Journal of Anyang Normal University, 2014 (5): 148-150.

[3] Wang Zhu. Reason Lights Passion; Passion Lights Reason - Thoughts on Patriotic Education in Colleges in the New Era of China.China Memorial Research, 2013 (1): 243-250.

[4] Zhao Shengyang. Analysis of Patriotism Education Innovation for Contemporary College Students -- Taking Huazhong University of Science and Technology Institute of Mandarin as Example. Economic Perspective, 2012 (16): 148-150.

[5] Liu Shulin, Sun Moli. New Thinking on Colleges Patriotic Education. Literature Education (middle), 2015 (2): 82 